\title{
A case of irreversible bradycardia after rituximab therapy for diffuse large B-cell lymphoma
}

\author{
Nway Le Ko Ko ${ }^{*}$, Nareg Minaskeian and Hicham Z. El Masry
}

\begin{abstract}
This is a case of a middle-aged woman with underlying cardiac conduction system with episodes of AV Wenckebach, who subsequently developed significant AV conduction system abnormalities after receiving one standard dose of Rituximab infusion for diffuse large B-cell lymphoma. Rituximab, being a monoclonal antibody against CD-20 antigen, is effective in treatment of B-cell lymphoma but may also cause bradyarrythmias likely due to the calcium ion channel property of CD-20 antigen.
\end{abstract}

Keywords: Rituximab, High grade AV block, Complete AV block, Bradyarrythmia, Diffuse large B cell lymphoma

\section{Introduction}

Rituximab is a monoclonal antibody directed against the CD20 antigen. The chimeric antibody has been used in the treatment of B-cell lymphoma and binds to the surface antigen activating complement-mediated cell toxicity. Cardiac complications related to Rituximab have been reported including cardiomyopathy and myocardial infarction. Rituximabinduced cardiac arrhythmias have been rarely reported.

We report a patient with sinus dysfunction and paroxysmal high-grade AV block after a single dose of Rituximab used for treatment of diffuse large B cell lymphoma.

\section{Case}

Our patient is a 56-year-old lady with no known cardiovascular condition other than controlled hypertension who presented to our hospital with an insidious onset of bilateral lower extremity lymphedema, and an obstructive uropathy with secondary acute kidney injury. Her initial work up was revealing of a large pelvic mass and extensive lymphadenopathy for which she underwent lymph node, pelvic mass and bone marrow biopsies. A confirmed diagnosis of high-

\footnotetext{
* Correspondence: koko.nway@mayo.edu

Department of Cardiovascular Medicine, Mayo Clinic Arizona, Phoenix, AZ, USA
}

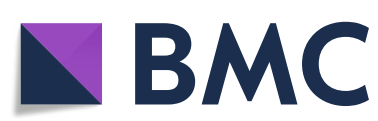

grade lymphoma, most likely a follicular lymphoma transformed into diffuse large B cell lymphoma (DLBCL), required her to be started on R-ECPOCH therapy (Rituximab, Etoposide, Prednisone, Vincristine, Cyclophosphamide and Doxorubicin). Patient reported an excellent pre-morbid functional status, and was a regular volleyball player and a walker prior to the last few months. She received the first dose of Rituximab $375 \mathrm{mg} / \mathrm{m}^{2}$ over $36 \mathrm{~h}$ along with Methylprednisolone and Doxorubicin as part of her combination chemotherapy. Patient received a total of $800 \mathrm{mg}$ of Rituximab over $36 \mathrm{~h}$.

Upon assessment of the patient, her laboratory parameters revealed chronic microcytic anemia with hemoglobin of 6.9 $\mathrm{mg} / \mathrm{dl}$ and leukocytosis with white blood cell count of $11 \times$ $10^{9} / \mathrm{L}$ with neutrophilia and lymphopenia. Her kidney function and electrolytes were normal. Her echocardiogram was evident for normal biventricular function and global longitudinal strain without any significant valvular anomalies. Initial EKG was apparent for underlying conduction system disease with episodes of AV Wenckebach. In telemetry records, the rhythm had been predominantly in 2:1 AV blocks with additional periods of transient complete AV block with a ventricular rate down to 30s with narrow QRS complexes (Fig. 1). Over the continued observation for $24 \mathrm{~h}$, it was evident

(c) The Author(s). 2020 Open Access This article is licensed under a Creative Commons Attribution 4.0 International License, which permits use, sharing, adaptation, distribution and reproduction in any medium or format, as long as you give appropriate credit to the original author(s) and the source, provide a link to the Creative Commons licence, and indicate if changes were made. The images or other third party material in this article are included in the article's Creative Commons licence, unless indicated otherwise in a credit line to the material. If material is not included in the article's Creative Commons licence and your intended use is not permitted by statutory regulation or exceeds the permitted use, you will need to obtain permission directly from the copyright holder. To view a copy of this licence, visit http://creativecommons.org/licenses/by/4.0/. The Creative Commons Public Domain Dedication waiver (http://creativecommons.org/publicdomain/zero/1.0/) applies to the data made available in this article, unless otherwise stated in a credit line to the data. 


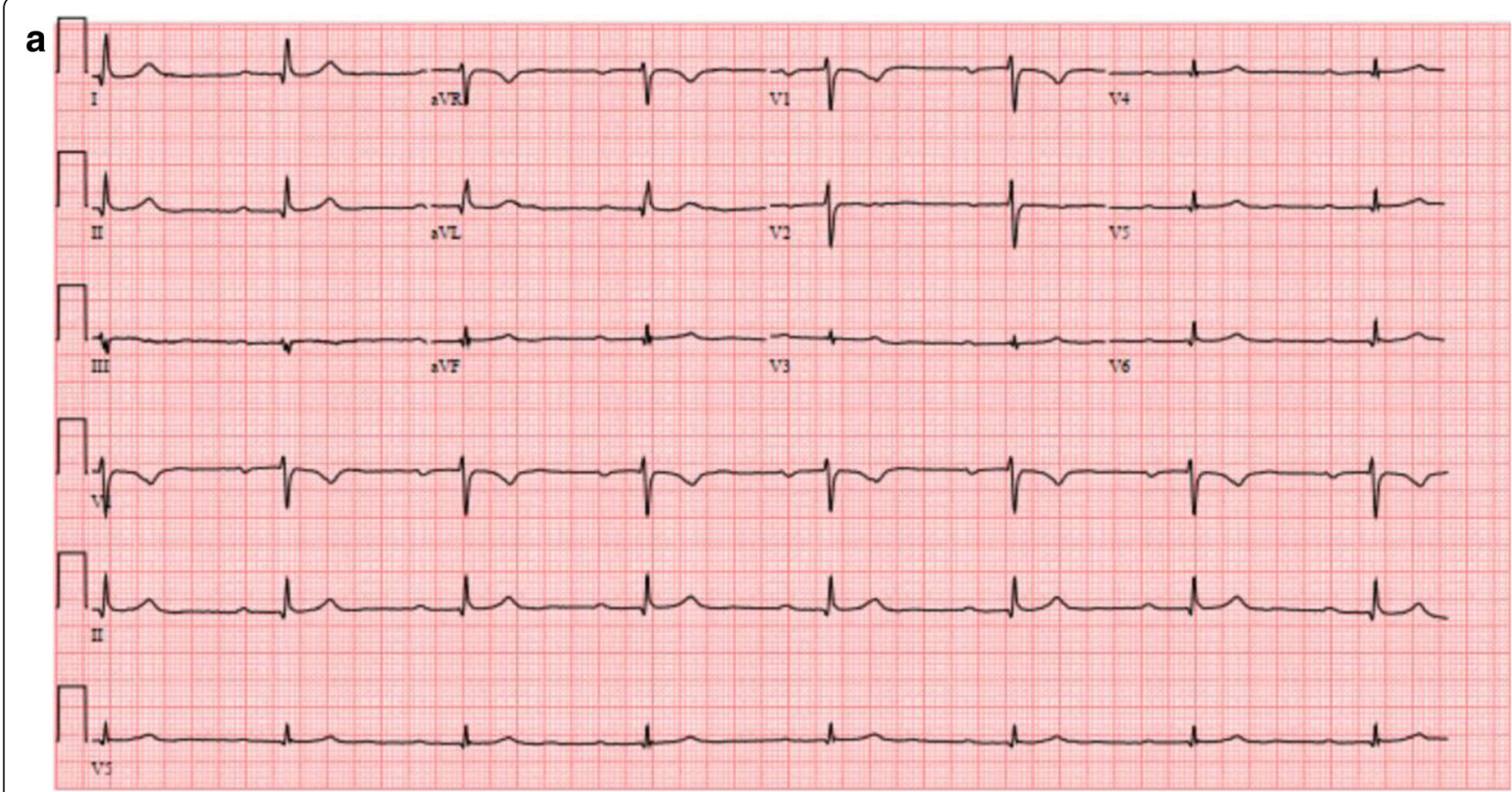

b
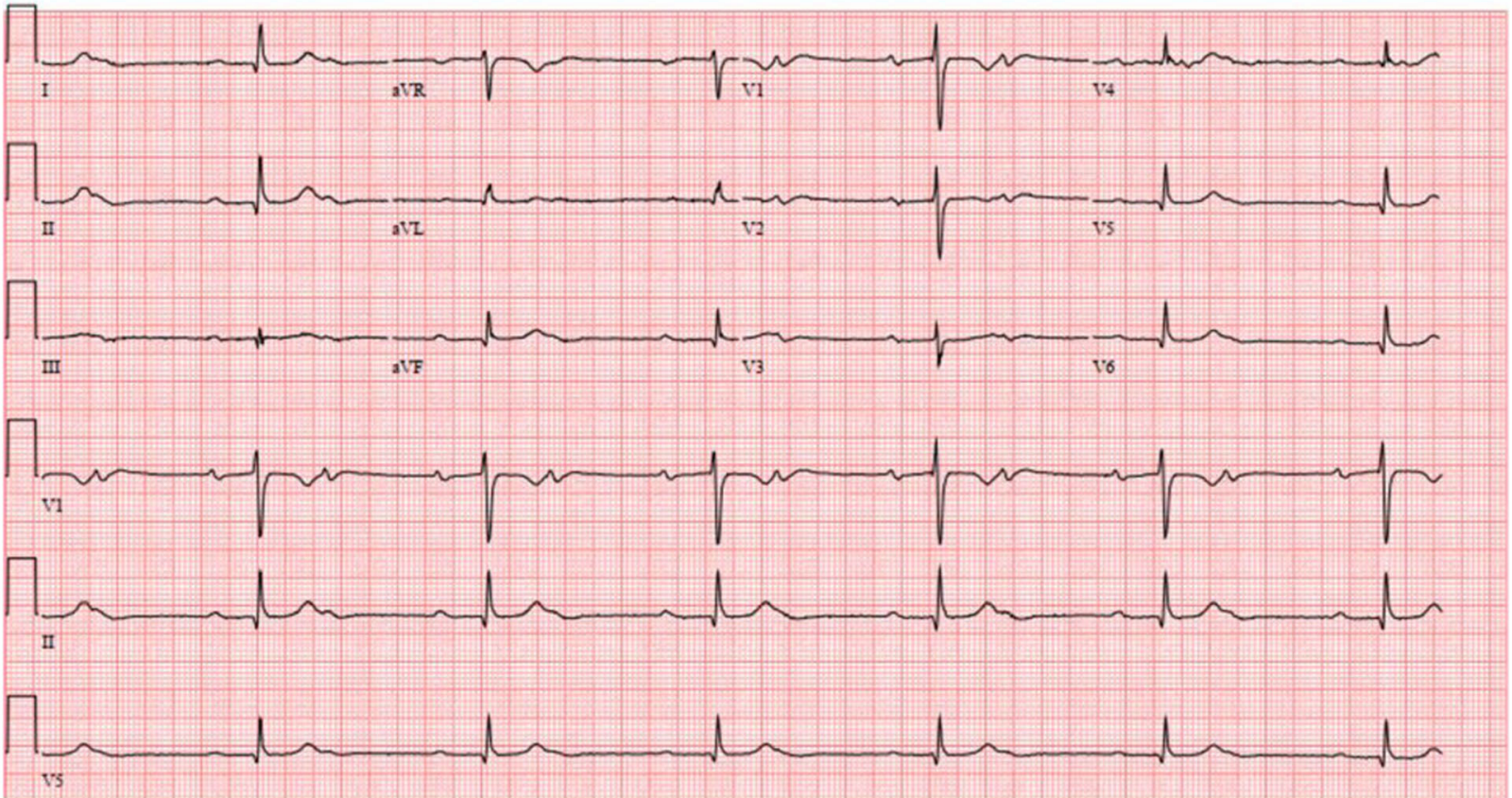

Fig. 1 Showing the patient's serial electrocardiograms: a baseline tracing demonstrating sinus rhythm with first degree AV block, b sinus rhythm with 2:1 AV block

that with exercise, her heart rate increased with the rhythm going back into Mobitz type $1 \mathrm{AV}$ block consistent with AV nodal level of conduction block. However, for most of the time, the predominant rhythm was 2:1 AV block with continued occurrence of episodes of high-grade AV block and junctional escape rhythm. Reports of occasional dizziness and an episode of near syncope with worsening bradycardia hence lead to discontinuation of Rituximab therapy as a careful review of her medications did not reveal any negative chronotropic or dromotropic agent that might explain worsening bradycardia (Fig. 2). The calculated Naranjo Adverse Drug Reaction Probability Score of 3 with Rituximab in this case indicated that her AV block was possibly caused by adverse drug effect of Rituximab, as it followed a temporal sequence after Rituximab and it could be explained by the characteristic of her AV block (Supplementary Appendix, Table 1) [1]. Her 


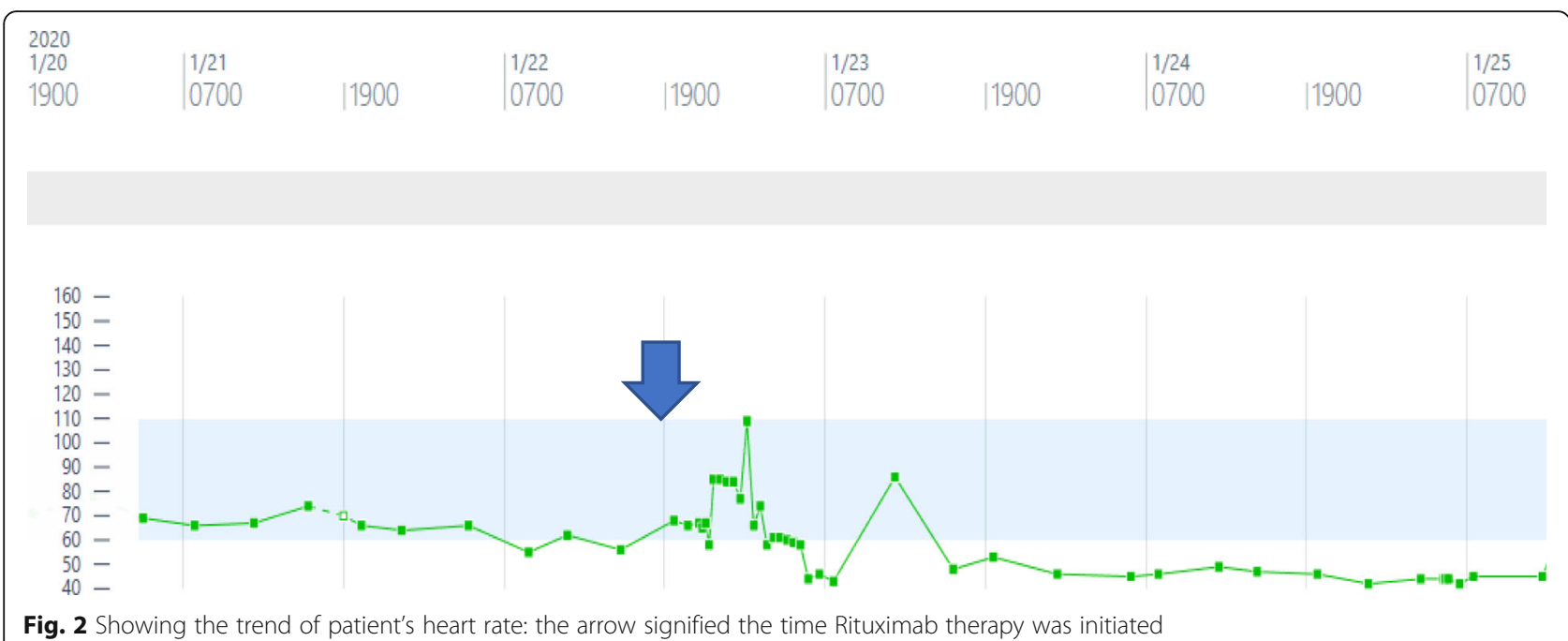

bradyarrythmia persisted more than $48 \mathrm{~h}$ after interruption of her infusion and a pacemaker was implanted at that point. The first time pacemaker interrogation revealed right atrial pacing percentage of $2.3 \%$ and right ventricular pacing percentage of $99.3 \%$ with the lower rate limit set at 60 . The patient received another round of Rituximab in a month. The following pacemaker interrogation revealed right atrial pacing percentage of $6.96 \%$ and right ventricular pacing percentage of $99.7 \%$ with the lower rate limit set at 60 beats per minute.

\section{Discussion}

Infusion reactions associated with Rituximab therapy have been reported including cardiac arrhythmia such as monomorphic ventricular tachycardia, supraventricular tachycardia, trigeminy, and irregular pulse [2-4]. Moreover, it can also cause bradycardia and AV blocks [2, 5, 6]. Based on our knowledge, this is the second case report of Rituximab causing high grade AV block as there has only been one case report of complete AV block after the fifth dose of Rituximab [5]. In the first reported case, the patient did not have underlying conduction system disease, but our patient did although they both received similar dose of Rituximab per cycle for the indication of DLBCL. In our case, it is likely that the underlying conduction system disease had put our patient into high grade AV block just after the first dose of Rituximab. The half-life elimination of Rituximab is proportional to dosage. After an initial dose of $375 \mathrm{mg} / \mathrm{m}^{2}$, the average half-life of Rituximab is 3.2 days (range, 1.3-6.4 days) [7]. For our patient, the AV block onset within 2 days of Rituximab infusion, and her conduction system failed to recover after more than $48 \mathrm{~h}$ of monitoring. There have been several explanations of the mechanism of Rituximab affecting the cardiac conduction system. Per Poterucha et.al., it was hypothesized that CD20 antigen may function as a calcium-ion channel. Rituximab can induce the death of CD20+ cells in many ways such as direct cytotoxicity mediated by antibody dependent cells and complement cascade as well as by indirect effects like apoptosis, structural changes and sensitization of malignant cells to chemotherapy [8]. Therefore, it is likely that Rituximab affects cardiac conduction system by inhibiting the calciumion-channel properties of the CD20 antigen on the cardiac myocytes. This mechanism appears to be the most plausible pathogenesis of our patient's bradycardia: infusion initiation was associated with sinus bradycardia and worsening AV block which appears to be at the AV nodal level (improved conduction with exercise and narrow junctional escape with transient high grade AV block). A calcium channel blocking effect at both the sinus and atrioventricular node levels is a unifying explanation of those observations. Other hypotheses include elevated transforming growth factor-B promoting growth of reticulin fiber in cardiac myocytes which impairs contractility and conduction [9] as well as release of cytokines, such as interleukin-6 and tumor necrosis factor-alpha [5]. These cytokines can also mediate ventricular dysfunction, acute coronary syndrome, and myocarditis in addition to tachy-arrhythmias or brady-arrhythmias [10].

\section{Conclusion}

With this case report, we intend to highlight the effect of Rituximab on cardiac conduction due to calcium channel property of CD20 antigen. FDA has cautiously provided recommendations to discontinue infusions for serious or life-threatening cardiac arrhythmias and perform cardiac monitoring during and after each infusion of Rituximab for patients who develop clinically significant arrhythmias, or who have a history of arrhythmia, angina or conduction system disease like our patient $[10,11]$. We would also recommend telemetry monitoring for patients who demonstrate any baseline evidence of sinus node dysfunction or conduction abnormalities predisposing them to symptomatic bradycardia with Rituximab therapy and its calcium channel blocking property. 


\section{Appendix}

Table 1 Naranjo Adverse Drug Reaction Probability Scale

\begin{tabular}{|c|c|c|c|c|}
\hline Question & Yes & No & Do not know & Score \\
\hline Are there previous conclusive reports on this reaction? & +1 & 0 & 0 & +1 \\
\hline Did the adverse event appear after the suspected drug was administered? & +2 & -1 & 0 & +2 \\
\hline Did the adverse event improve when the drug was discontinued or a specific antagonist was administered? & +1 & 0 & 0 & 0 \\
\hline Did the adverse event reappear when the drug was readministered? & +2 & -1 & 0 & 0 \\
\hline Are there alternative causes that could on their own have caused the reaction? & -1 & +2 & 0 & 0 \\
\hline Did the reaction reappear when a placebo was given? & -1 & +1 & 0 & 0 \\
\hline Was the drug detected in blood or other fluids in concentrations known to be toxic? & +1 & 0 & 0 & 0 \\
\hline Was the reaction more severe when the dose was increased or less severe when the dose was decreased? & +1 & 0 & 0 & 0 \\
\hline Did the patient have a similar reaction to the same or similar drugs in any previous exposure? & +1 & 0 & 0 & 0 \\
\hline Was the adverse event confirmed by any objective evidence? & +1 & 0 & 0 & 0 \\
\hline Total score & & & & 3 \\
\hline
\end{tabular}

\section{Acknowledgements}

Not applicable.

\section{Authors' contributions}

All authors contributed in generating the manuscript. All authors read and approved the final manuscript.

\section{Funding}

None.

\section{Availability of data and materials}

Not applicable.

\section{Ethics approval and consent to participate}

Not applicable.

\section{Consent for publication}

Not applicable.

\section{Competing interests}

The authors declare that they have no competing interests.

Received: 7 July 2020 Accepted: 16 September 2020

Published online: 13 October 2020

\section{References}

1. Adverse Drug Reaction Probability Scale (Naranjo) in Drug Induced Liver Injury. LiverTox: Clinical and Research Information on Drug-Induced Liver Injury. Bethesda (MD): National Institute of Diabetes and Digestive and Kidney Diseases; 2012.

2. Arai Y, Tadokoro J, Mitani K. Ventricular tachycardia associated with infusion of rituximab in mantle cell lymphoma. Am J Hematol. 2005;78:317-8.

3. Coiffier B, Lepage E, Briere J, et al. CHOP chemotherapy plus rituximab compared with $\mathrm{CHOP}$ alone in elderly patients with diffuse large-B-cell lymphoma. N Engl J Med. 2002;346:235-42.

4. Dillman RO. Infusion reactions associated with the therapeutic use of monoclonal antibodies in the treatment of malignancy. Cancer Metastasis Rev. 1999:18:465-71.

5. Foran JM, Rohatiner AZ, Cunningham D, et al. European phase II study of rituximab (chimeric anti-CD20 monoclonal antibody) for patients with newly diagnosed mantle-cell lymphoma and previously treated mantle-cell lymphoma, immunocytoma, and small B-cell lymphocytic lymphoma. J Clin Oncol. 2000;18:317-24.

6. Cervera Grau JM, Esquerdo Galiana G, Belso Candela A, Llorca Ferrandiz C, Juarez Marroqui A, Macia ES. Complete atrioventricular block induced by rituximab in monotherapy in an aged patient with non-Hodgkin's diffuse large B-cell lymphoma. Clin Transl Oncol. 2008;10:298-9.

7. Maloney DG, Liles TM, Czerwinski DK, et al. Phase I clinical trial using escalating single-dose infusion of chimeric anti-CD20 monoclonal antibody (IDEC-C2B8) in patients with recurrent B-cell lymphoma. Blood. 1994;84: 2457-66.

8. Cerny $T$, Borisch $B$, Introna $M$, Johnson $P$, Rose AL. Mechanism of action of rituximab. Anti-Cancer Drugs. 2002;13(Suppl 2):S3-10.

9. Kanamori $H$, Tsutsumi $Y$, Mori $A$, et al. Delayed reduction in left ventricular function following treatment of non-Hodgkin's lymphoma with chemotherapy and rituximab, unrelated to acute infusion reaction. Cardiology. 2006;105:184-7.

10. Cheungpasitporn W, Kopecky SL, Specks U, Bharucha K, Fervenza FC. Nonischemic cardiomyopathy after rituximab treatment for membranous nephropathy. J Renal Injury Prev. 2017;6:18-25.

11. Rituxan official FDA information, side effects and uses [Internet]. 2007 Mar [cited 2010 Mar 2]. Available from: http://www.drugs.com/pro/rituxan.html.

\section{Publisher's Note}

Springer Nature remains neutral with regard to jurisdictional claims in published maps and institutional affiliations.

Ready to submit your research? Choose BMC and benefit from:

- fast, convenient online submission

- thorough peer review by experienced researchers in your field

- rapid publication on acceptance

- support for research data, including large and complex data types

- gold Open Access which fosters wider collaboration and increased citations

- maximum visibility for your research: over $100 \mathrm{M}$ website views per year

At $\mathrm{BMC}$, research is always in progress.

Learn more biomedcentral.com/submissions 